\title{
Candidate target genes for loss of heterozygosity on human chromosome |7q2|
}

\author{
L DeMarchis', C Cropp', ZM Sheng', S Bargo' and R Callahan*,I \\ 'Mammary Biology and Tumorigenesis Laboratory, National Cancer Institute, Bethesda, MD 20892, USA
}

Loss of heterozygosity $(\mathrm{LOH})$ on chromosome $17 \mathrm{q} 21$ has been detected in $30 \%$ of primary human breast tumours. The smallest common region deleted occurred in an interval between the DI7S746 and DI7S846 polymorphic sequences tagged sites that are located on two recombinant PI-bacteriophage clones of chromosome 17q2 I: 122F4 and 50HI, respectively. To identify the target gene for $\mathrm{LOH}$, we defined a map of this chromosomal region. We found the following genes: JUP, FK506BPI0, SC65, Gastrin (GAS) and HAPI. Of the genes that have been identified in this study, only JUP is located between DI7S746 and DI7S846. This was of interest since earlier studies have shown that JUP expression is altered in breast, lung and thyroid tumours as well as cell lines having $\mathrm{LOH}$ in chromosome $17 \mathrm{q} 21$. However, no mutations were detected in JUP using single-strand conformation polymorphism analysis of primary breast tumour DNAs having $\mathrm{LOH}$ at $17 \mathrm{q} 21$. We could find no evidence that the transcription promoter for JUP is methylated in tumour DNAs having $\mathrm{LOH}$ at $17 \mathrm{q} 21$. We suspect that the target gene for $\mathrm{LOH}$ in primary human breast tumours on chromosome 17q21 is either JUP and results in a haploinsufficiency for expression or may be an unidentified gene located in the interval between DI7S846 and JUP.

British Journal of Cancer (2004) 90, 2384-2389. doi:I0.1038/sj.bjc.660I848 www.bjcancer.com

Published online 25 May 2004

(c) 2004 Cancer Research UK

Keywords: chromosome 17q21; loss of heterozygosity; plakoglobin

We (Cropp et al, 1993; Cropp et al, 1994), and others (reviewed in (Bieche et al, 1997; Osborne and Hamshere, 2000), have shown that sporadic human breast carcinomas are characterised by the frequent loss of heterozygosity $(\mathrm{LOH})$ on chromosome 17q1221. A common speculation of these studies, based on Knudson's work (Knudson, 1971), is that LOH reveals a recessive somatic mutation in a gene, designated a tumour suppressor gene, within the other unaffected homologous chromosome. We have defined a region, using 17 polymorphic sequences tagged sites (STS), on human chromosome 17q21 that is affected by LOH in 30\% of 130 sporadic breast tumours spanning the region between D17S746 to D17S846 (Cropp et al, 1994). Two P1-bacteriophage clones, 122F4 and $50 \mathrm{H} 1$, of human genomic DNA were identified that contain D17S746 and D17S846, respectively (Albertsen et al, 1994 and unpublished data). We have determined, partially, the nucleotide sequence of $122 \mathrm{~F} 4$ and $50 \mathrm{H} 1$ as a strategy to identify candidate genes that could be targets for mutation in breast tumour DNAs having $\mathrm{LOH}$ in this region of chromosome $17 \mathrm{q} 21$. In the present communication, we identify six genes that are located on chromosome $17 \mathrm{q} 21$, their relative gene order and their transcriptional orientation. This study compliments the Draft Human Genome Nucleotide Sequence in that it physically locates the Plakoglobin (JUP) gene between the two polymorphic markers, D17S746 and D17S846, previously used to identify the smallest common region of $\mathrm{LOH}$ in sporadic breast cancer (Cropp et al,

*Correspondence: Dr R Callahan, National Cancer Institute, Building 10/ Room 5B50, Bethesda, MD 20892, USA; E-mail: rc54d@nih.gov Received 28 July 2003; revised 4 March 2004; accepted I I March 2004; published online 25 May 2004
1994). Analysis of breast tumour DNAs having $\mathrm{LOH}$ at $17 \mathrm{q} 21$ revealed no mutations in JUP, SC65, FK506BP10 and MGC20781 genes that are expressed in normal breast epithelium. JUP has also been screened for methylation of its transcription promoter regions to determine if an epigenetic mechanism could affect the expression of the remaining allele such as that found for FHIT in breast tumours (Yang et al, 2002). No methylation has been found in the series of 10 sporadic breast tumour DNAs having $\mathrm{LOH}$ at chromosome $17 \mathrm{q} 12-\mathrm{q} 21$.

\section{MATERIALS AND METHODS}

\section{Characterisation of $17 \mathrm{q} 12-21$}

Two P1 phages clones were used to analyse the $17 \mathrm{q} 12-\mathrm{q} 21$ region: 122F4 and $50 \mathrm{H} 1$ (generously provided by Dr Ray White, Department of Oncological Sciences, Huntsman Cancer Institute, University of Utah, Salt Lake City, UT, USA). Libraries of 122F4 and $50 \mathrm{H} 1$ were constructed using standard techniques with BamHI or SSTI genomic restriction fragments, respectively, cloned into the pBluescript II KS $(+)$ vector (Stratagene, La Jolla, CA, USA) (Miyazaki et al, 1999). Subclones were subsequently ordered by size, restriction enzyme and nucleotide end-sequence analysis using universal primers from the vector. Nucleotide sequence analysis was performed using the ABI Big Dye Terminator sequencing kit (PE Applied Biosystems, Foster City, CA, USA) according to the manufacturer's instructions on an ABI 377 automated sequencer from PE Applied Biosystems (Foster City, CA, USA). The alignment of nucleotide sequences was determined with the Sequence Analysis Software Package by Genetics 
Computer Group (GCG), Inc. (Smithies et al, 1981). Within the GCG package fragment assembly was performed by the fragment assembly system based on the method of Staden (1980). Comparison of different sets of nucleotide sequences was analysed by the Best-Fit sequence alignment program (Needleman and Wunsch, 1970; Smith and Waterman, 1981). The genomic sequences obtained were compared using BLAST query with the GenBank. Colony hybridisation (Miyazaki et al, 1999) was used to identify additional clones of overlapping or adjacent restriction fragments that contained particular genes or exons of genes. Probes for colony hybridisation were cDNA clones for: the mouse homologue of FK506BP10 (generously provided by Dr Stephanie L Simek, Science Applications International Corp., NCI-Frederick Cancer Research and Development Center, MD, USA) (Coss et al, 1995), human JUP (pHPG Ca 2.1, generously provided by $\mathrm{Dr}$ Werner W Franke, German Cancer Research Center, Heidelberg, Germany) (Franke et al, 1989) and human EST clones (Research Genetics, Huntsville, AL, USA) for SC65 and MGC20781. Each probe was labelled with $\left[\alpha_{-}^{32} \mathrm{P}\right] \mathrm{dCTP}$ by random priming (Rediprime II kit, Amersham, Piscataway, NJ, USA).

\section{Reverse trancriptase-polymerase chain reaction (RT - PCR) analysis}

For JUP expression, an RT-PCR assay was performed, using a Superscript One-Step RT-PCR kit with Platinum Taq Polymerase from Invitrogen (Carlsbad, CA, USA). Normal tissue total RNA (10 ng), purchased from Clontech, was used as template. The JUP primers for Exon 1A were: forward, 5'-CCGAGCTCAGTTCGCTGT-3'; reverse, 5'-TCGTTGAGC AGTTTGGTGAG-3'; for Exon 1B were: forward, $5^{\prime}$-ACCCGCT TTCCTGAAAGAAT-3'; reverse, 5'-AGCAGAAGCGAGAICTG TCCT-3'. The GAPDH primers were used as a control for the amount of RNA tested: forward, 5'-CCCTTCATTGACCTCAACTAC- $3^{\prime}$; reverse, $5^{\prime}$ CCACCTTCTTGATGTCATCAT- $3^{\prime}$ to amplify a 600 base pair (bp) fragment. A measure of $25 \mu \mathrm{l}$ of $2 \times$ mixture containing $0.4 \mathrm{~mm}$ of each dNTP, $2.4 \mathrm{~mm} \mathrm{MgSO}_{4}, 10 \mu \mathrm{m}$ of each primer, $1 \mu \mathrm{l}$ of $\mathrm{Rt} /$ Platinum Taq mix and autoclaved (RNAse-free) distilled water up to $50 \mu \mathrm{l}$ of total reaction volume. The cDNA synthesis and predenaturation was performed at $52^{\circ} \mathrm{C}$ for $30 \mathrm{~min}$ for one cycle and the PCR amplification was performed for 35 cycles at $94^{\circ} \mathrm{C}$ for $15 \mathrm{~s}, 52^{\circ} \mathrm{C}$ for $30 \mathrm{~s}$ and $72^{\circ} \mathrm{C}$ for $1 \mathrm{~min}$. A final extension was performed at $72^{\circ} \mathrm{C}$ for $10 \mathrm{~min}$.

\section{Mutation screening}

'Cold' single-strand conformation polymorphism (SSCP) analysis was performed as described by Hongyo et al (1993) to identify mutations in JUP genomic from breast tumours having LOH on chromosome 17q21. The primers used correspond to intron sequences located $5^{\prime}$ and $3^{\prime}$ of the particular exon (Table 1). After an initial denaturation cycle of $94^{\circ} \mathrm{C}$ for $5 \mathrm{~min}$, amplification from $100 \mathrm{ng}$ genomic DNA was carried out with two cycles each of $\left(94^{\circ} \mathrm{C}\right.$ $\left.10 \mathrm{~min}, 66^{\circ} \mathrm{C} 10 \mathrm{~min}, 72^{\circ} \mathrm{C} 20 \mathrm{~min}\right),\left(94^{\circ} \mathrm{C} 10 \mathrm{~min}, 64^{\circ} \mathrm{C} 10 \mathrm{~min}\right.$, $\left.72^{\circ} \mathrm{C} 20 \mathrm{~min}\right),\left(94^{\circ} \mathrm{C} 10 \mathrm{~min}, 62^{\circ} \mathrm{C} 10 \mathrm{~min}, 72^{\circ} \mathrm{C} 20 \mathrm{~min}\right),\left(94^{\circ} \mathrm{C}\right.$ $\left.10 \mathrm{~min}, 60^{\circ} \mathrm{C} 10 \mathrm{~min}, 72^{\circ} \mathrm{C} 20 \mathrm{~min}\right)$ and then 25 cycles of $\left(94^{\circ} \mathrm{C}\right.$ $10 \mathrm{~min}, 56^{\circ} \mathrm{C} 10 \mathrm{~min}, 72^{\circ} \mathrm{C} 20 \mathrm{~min}$ ) with a final extension cycle at $72^{\circ} \mathrm{C}$ for $7 \mathrm{~min}$. All SSCP products were analysed on $4-20 \%$ precast polyacrylamide gels (Novex, San Diego, CA, USA) in TBE at $325 \mathrm{~V}$ for $60 \mathrm{~min}$ at a primer set-dependent temperature (see Table 1) using the manufacture's conditions. The gels were stained with SYBR Green II (Molecular Probes, Inc., Eugene, OR, USA) using the manufacture's conditions, visualised using a $340 \mathrm{~nm}$ UV viewing box and photographed.

\section{Methylation-specific PCR for the JUP transcription promoter}

As a positive control for CpG methylation of genomic DNA, we have methylated a restriction fragment of recombinant genomic DNA containing the JUP transcription promoter. This was performed using the SssI methylase (CpG methylase) (New England Biolabs, Inc., Beverly, MA, USA) and the manufacturer's conditions. A PCR-based experimental protocol was used to detect hypermethylation of genomic DNA (Herman et al, 1996; Dracopoli et al, 1998). Briefly, $1 \mu \mathrm{g}$ of primary breast tumour genomic or control recombinant DNA containing the JUP promoter was treated with sodium bisulphite. Modified and nonmodified control and tumour DNA were used as templates in PCR reactions with FastStart Taq DNA Polymerase (Roche Molecular Biochemicals, Indianapolis, IN, USA). The reaction mixture contained $5 \mu \mathrm{l}$ of $10 \times$ PCR buffer (containing $2 \mathrm{mM} \mathrm{MgCl}_{2}$ ), $1 \mu \mathrm{l}$ of $10 \mathrm{~mm}$ PCR Nucleotide Mix, $250 \mathrm{ng}$ of each primer, $0.4 \mu \mathrm{l}$ FastStart Taq DNA Polymerase (2 U), $1 \mu \mathrm{l}$ of bisulphite modified DNA and distilled water to $50 \mu \mathrm{l}$ total volume. The primer pairs for unmethylated DNA: PgU $\mathrm{F}$, forward 5'-TTGGAGTAGTTGTTGTTTGATTGTGTT-3'; PgUR reverse 5'-CAAACCAAATCAAAATCAAACCAA-3'; and for methylated DNA: PgMeth F forward $5^{\prime}$-TAGTCGTCGTTCGATCGCGTC-3'; PgMethR reverse 5'-AACCGAATCGAAATCGAACCG-3' have been previously described by Potter et al (2001) and lead to the amplification of 84 and $76 \mathrm{bp}$ fragments, respectively. The PCR reactions were placed in an Applied Biosystems GeneAmp PCR System 9700 thermal cycler and activated at $95^{\circ} \mathrm{C}$ for $4 \mathrm{~min}$, denatured at $95^{\circ} \mathrm{C}$ for $30 \mathrm{~s}$, annealed at $56^{\circ} \mathrm{C}$ for $30 \mathrm{~s}$ and elongated at $72^{\circ} \mathrm{C}$ for $1 \mathrm{~min}$ for 35 cycles. A final extension of $72^{\circ} \mathrm{C}$ for $7 \mathrm{~min}$ and a $4^{\circ} \mathrm{C}$ indefinite hold

Table I Primers for the amplification of JUP exons

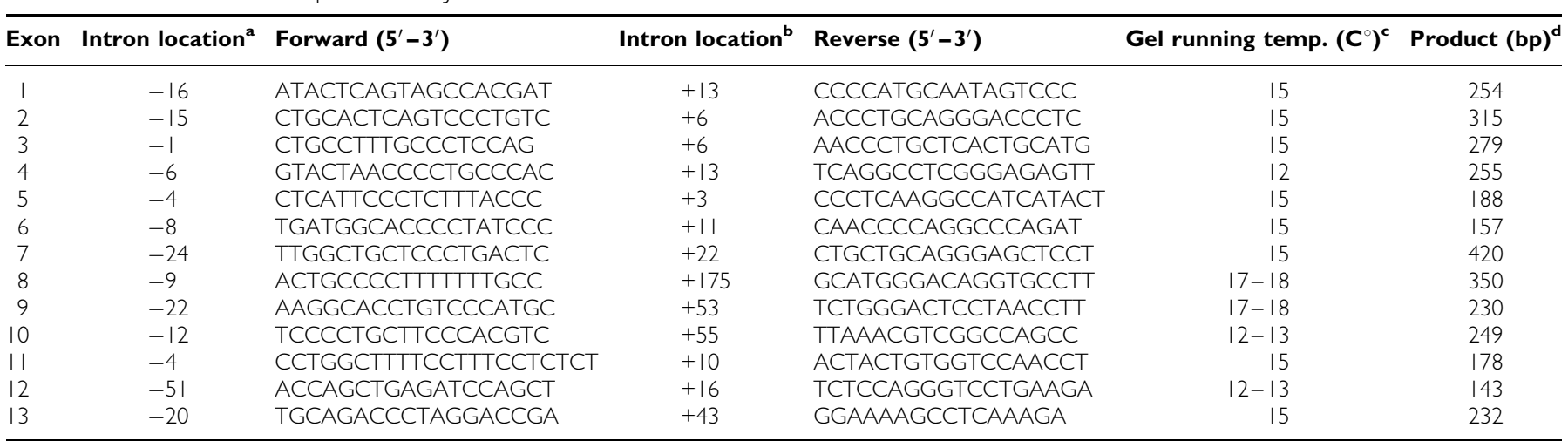

The forward primer for Exon I starts 16 bp $5^{\prime}$ to the translation start signal, for the other Exons the number given is the base pair separating the last base of the primer and the

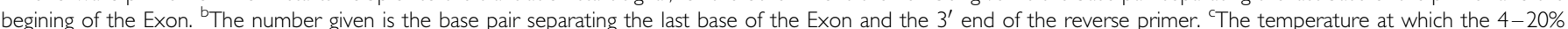
polyacrylamide gel was run. ${ }^{\mathrm{T}}$ The size of the PCR product is indicated base pairs. 


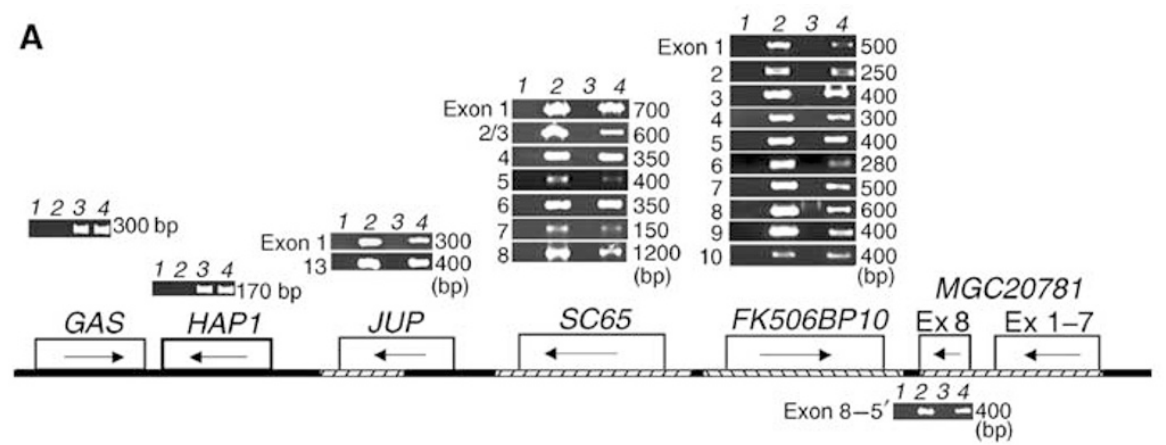

$50 \mathrm{H} 1 \mathrm{P} 1$

122F4 P1

B
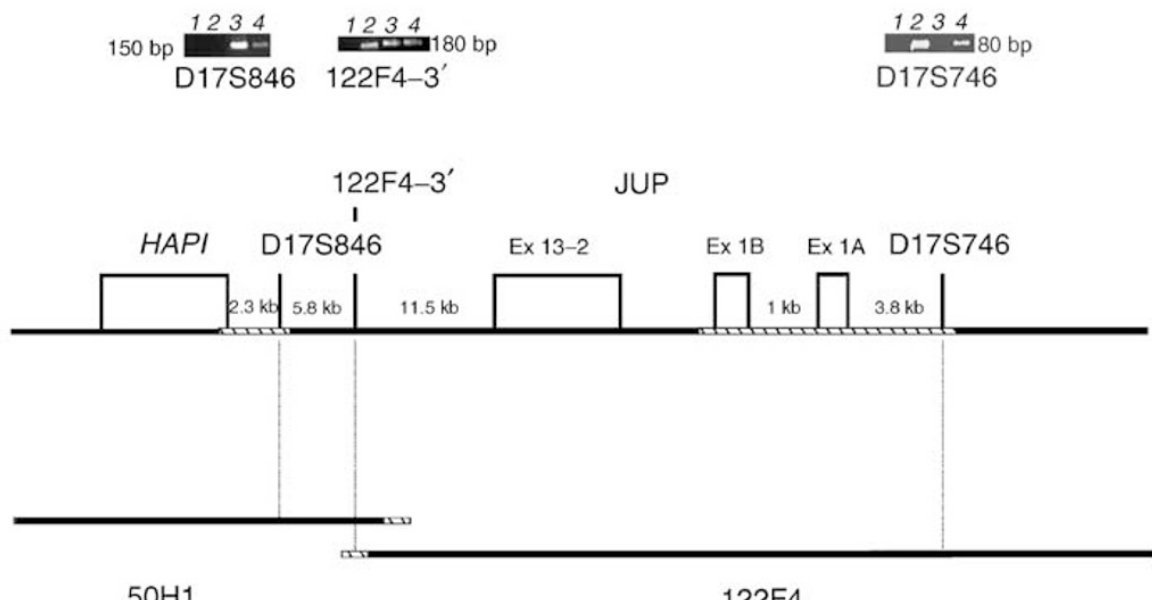

$50 \mathrm{H} 1$

$122 \mathrm{~F} 4$

Figure I (A) A partial map of human chromosome 17q I2-q21. The PCR products of an analysis of the PI-phage clones are shown for the presence of exons corresponding to the indicated genes. The arabic numbers represent the templates used to perform the PCR amplification of the indicated exon: lane I, water control; lane 2, I22F4; lane 3,50HI PI-phage clones; lane 4, genomic DNA control. The intron/exon primers of all the genes are available upon request. The sizes of the PCR-amplified fragments are indicated in bp. The arrow indicates transcriptional orientation $5^{\prime}-3^{\prime}$ of the indicated genes. The portions of the map with right-hand hatch marks correspond to regions in which the nucleotide sequence of the exon/intron junctions was determined. The regions of the map in which the entire nucleotide sequence was determined are indicated with left-hand hatch marks. The centromeric end of the map is on the left and the telomeric end is on the right side. (B) A map of the region of chromosome $|7 \mathrm{q}| 2-\mathrm{q} 2 \mid$ affected by LOH. The positions of Exons IA, IB, the remainder of JUP exons and HAPI as well as DI7S846, I22F4-3' and DI7S746 on the chromosome map are indicated. The PCR products of an analysis of the $\mathrm{PI}$-phage clones, 50HI and I22F4, are shown for the presence of DI7S846, HUMI22F4-3' (accession number L32940) and DI7S746. The arabic numbers represent the templates used to perform the PCR amplification of the indicated exon: lane I, water control; lane 2, I22F4; lane 3, 50HI PI-phage clones; lane 4, genomic DNA control. The regions of the map in which the entire nucleotide sequence was determined are indicated with left-hand hatch marks.

completed the reaction. For analysis, $12 \mu \mathrm{l}$ of each PCR reaction was mixed with $5 \times$ Hi-Density TBE sample Buffer (Invitrogen, Carlsbad, CA, USA) and loaded onto a $6 \%$ TBE Gel (Invitrogen). The gel was run at $200 \mathrm{~V}$ for $30 \mathrm{~min}$, stained with ethidium bromide and visualised on a UV light box.

\section{RESULTS AND DISCUSSION}

To identify new genes with a potential tumour suppressor function and determine their position within the region of chromosome $17 q 12-21$ affected by $\mathrm{LOH}$, we have determined the nucleotide sequence of portions of the 122F4 and 50H1 P1-phage clones of human genomic DNA that span the region between the D17S846 (centromeric) and D17S746 (telomeric) polymorphic markers (Figure 1). Nucleotide sequence analysis of BamHI and SSTI fragments of $122 \mathrm{~F} 4$ demonstrated the presence of the JUP gene. Previous studies (Aberle et al, 1995; Whittock et al, 2000) localised JUP within this area of chromosome 17. In the present study, we can now physically link JUP to SC65 (Exons 1-8), FK506BP10 (Exons 1-10) and MGC20781 (Exon 8). FK506BP10 is a member of a family of genes that encode proteins that are immunophilins that bind FK506 and rifampysin and possess prolyl:prolyl isomerase activity (Siekierka et al, 1989; Standaert et al, 1990). The normal function of Fk506BP10-, SC65- and MGC20781-encoded proteins is not known. Only the last exon (Exon 8) of MGC20781 is located on 122F4. The results of a PCR analysis of the exons for each of these genes on 122F4 are shown in Figure 1A.

We have also localised by PCR analysis D17S746 and D17S846 on these P1-phage clones (Figure 1B). D17S846 is located $\sim 7.8 \mathrm{~kb}$ from one end of the recombinant genomic DNA in P1-phage 50H1 and is $2291 \mathrm{bp}$ from the transcription promoter region of HAP1. The D17S746 locus is present on $122 \mathrm{~F} 4$ but not on $50 \mathrm{H} 1$, suggesting that it is located near JUP. This observation was confirmed by nucleotide sequence analysis of a recombinant clone from a library of SSTI-digested 122F4 DNA. D17S746 is located $3865 \mathrm{bp}$ telomeric of JUP Exon 1A (Figure 1B). The HUM122F4- $3^{\prime}$ 
A

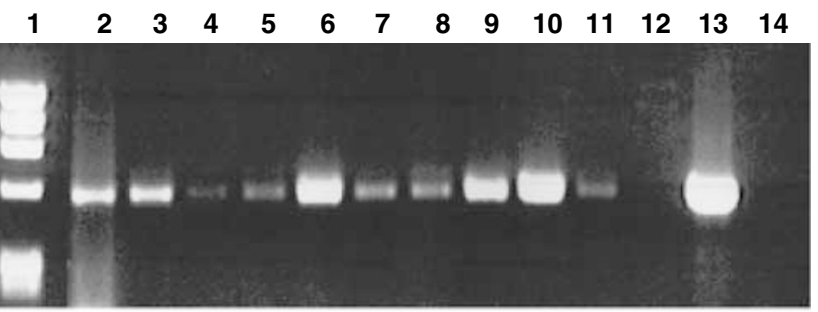

B
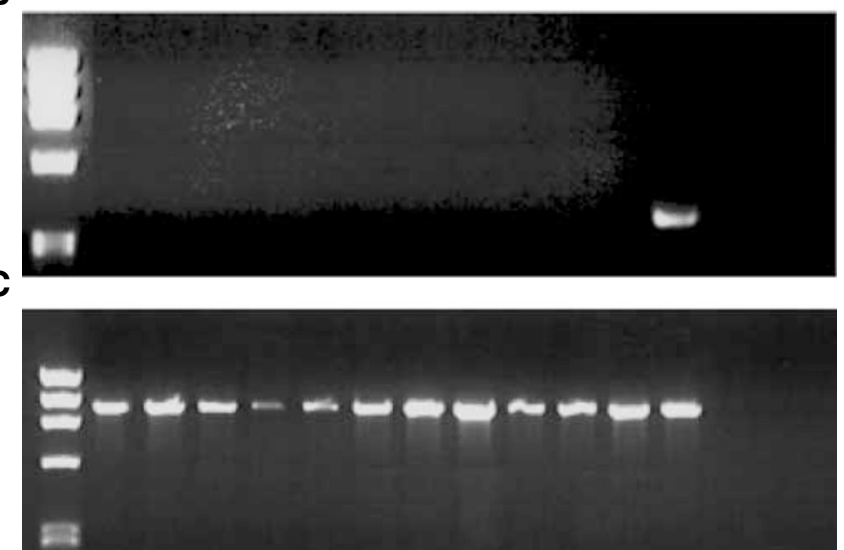

Figure 2 An RT-PCR assay of JUP Exon IA (A), Exon IB (B) and GAPDH (C) RNA expression. Lane I is Marker Haelll-digested phi XI74 DNA. RT-PCR was performed on RNA from: lane 2, heart; lane 3, kidney; lane 4, peripheral blood lymphocytes; lane 5, liver; lane 6, placenta; lane 7, lung; lane 8, muscle; lane 9, ovary; lane 10, mammary gland; lane II, small intestine; lane 12, EST-3958 I I cDNA containing Exon I B; lane I3, pHPG Ca 2.I cDNA containing Exon IA; lane 14, water.

STS locus is located $191 \mathrm{bp}$ from one end of the genomic fragment in the 122F4 P1-phage clone.

The transcriptional orientation of the genes could be deduced by PCR and nucleotide sequence analysis. Thus of the genes on 122F4, JUP Exon 13 is located $\sim 11.5 \mathrm{~kb}$ from the HUM122F4-3' STS locus (Figure 1). This is consistent with the direction of transcription being from the telomeric to centromeric regions of the chromosome. This analysis was also anchored with the observation that only Exon 8 of MGC20781 was found on 122F4 and is consistent with the transcriptional orientation of this gene being in the same direction as JUP (Figure 1). In addition, Exon 8 of MGC20781 could be linked to a $3.4 \mathrm{~kb}$ PCR fragment containing Exon 10 of $F K 506 B P 10$, which is consistent with the transcriptional orientation of FK506BP10 being in the opposite direction as JUP. Similarly, Exon 8 of SC65 and D17S746 were linked in an $11 \mathrm{~kb}$ PCR fragment (Figure 1) consistent with the transcriptional orientation of SC65 as being in the same direction as JUP. These results confirm the Human Genome Map and physically locate the STS loci HUM122F4-3' and D17S746, respectively.

As genes were identified in this study, we screened genomic DNA from 11 primary human tumours having $\mathrm{LOH}$ in this region of chromosome 17 by nucleotide sequence analysis. No missense, nonsense or frameshift mutations were detected in SC65, FK506BP10 or MGC20781 in these tumours DNAs. Gastrin (GAS) and HAP1 were not tested since they are not expressed in the mammary gland. When it was clear that among the genes that were analysed, only JUP was located between D17S746 and D17S846; JUP genomic DNA was tested by the more sensitive 'cold' SSCP analysis (Osborne et al, 1991; Hongyo et al, 1993) for mutations, none were found (data not shown).

JUP has two potential transcription promoters. JUP, Exon $1 \mathrm{~A}$ was expressed in 10 tissues tested (Figure 2), whereas Exon 1B could not be detected in any of these tissues (Figure 2). However,
A

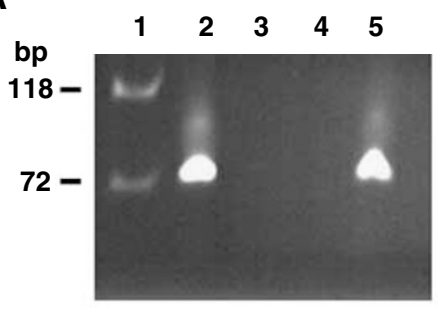

B

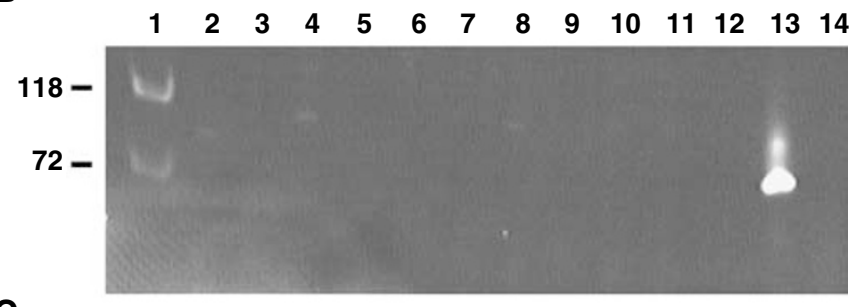

C

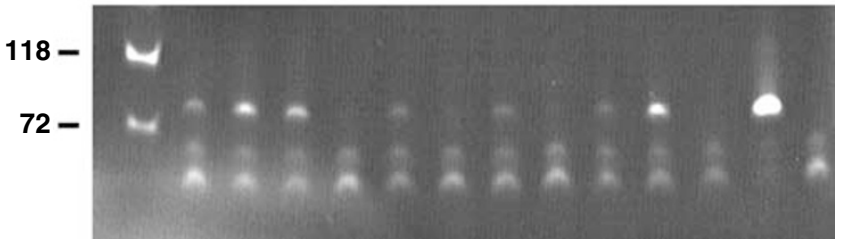

Figure 3 Methylation-specific PCR of the JUP promoter region in primary breast tumour DNAs having $\mathrm{LOH}$ on chromosome 17q21. (A) Test of primer pairs for PCR of unmethylated and in vitro methylated recombinant genomic DNA containing the JUP promoter region: lane I, Marker Haell-digested phi XI74 DNA; lane 2, methylated-specifc primers and methylated JUP genomic DNA; lane 3, methylated specifc primers and unmethylated UUP genomic DNA; lane 4, unmethylated specifc primers and methylated JUP genomic DNA; lane 5, unmethylated specifc primers and unmethylated UP genomic DNA. PCR analysis of primary breast tumour DNAs with methylation specific primers (B) or primers specific for unmethylated JUP genomic DNA (C). The DNAs were: lanel, Marker Haell-digested phi XI74 DNA; lane 2, tumour 16; lane 3, tumour 20; lane 4, tumour 26; lane 5, tumour30; lane 6, tumour 44; lane 7, tumour 62; lane 8, tumour 63; lane 9, tumour 89; lane 10, tumour 117; lane II, tumour 127; lane 12, unrelated genomic DNA; lane 13, control methylated recombinant JUP promoter region (B) and control unmethylated recombinant JUP promoter region (C); lane 14, water control.

five ESTs that contain Exon 1B from a placenta cDNA library (NIH_MGC_21) have been reported in the GenBank. One of these is the positive control shown in Figure 2B (lane 12).

Winn et al (2002) demonstrated that plakoglobin expression is reduced or absent in a subset of human lung cancers. Further they showed that re-expression of plakoglobin inhibits transformed cell growth, suggesting JUP is a tumour suppressor gene. Blanco et al (2002) found that $76 \%$ (13 out of 17) invasive ductal carcinomas of the breast had reduced levels of plakoglobin. Potter et al (2001) have shown that in some thyroid tumours and cell lines, which express low or undetectable levels of plakoglobin, the JUP promoter is hypermethylated. To see if a similar phenomenon affects the remaining JUP allele in breast tumours having $\mathrm{LOH}$ at chromosome 17q21, we have examined the methylation status of the transcription promoter region for JUP. The specificity of the primers for methylated and unmethylated JUP Exon 1A is shown in Figure 3A. No PCR product (Figure 3B, lanes 2-12) the size of the control fragment (lane 13) of methylated JUP Exon 1A was detected using the tumour DNAs as the template. However, as shown in Figure 3C, lanes 2-12, PCR products of the same size as the control (lane 13) for unmethylated DNA was detected with tumour DNA templates. JUP Exon 1B was not tested for its 
methylation status since it is not active in the mammary gland (Figure 2).

In conclusion, we have focused on $122 \mathrm{~F} 4$ and $50 \mathrm{H} 1 \mathrm{P} 1$-phage clones because they contain (Albertsen et al, 1994, and unpublished data) overlapping genomic DNA fragments that spanned a region of chromosome 17q21 affected by LOH. Our nucleotide sequence analysis of the ends of the genomic DNA in these P1phage clones is consistent with an overlap of $2.3 \mathrm{~kb}$. At the present time, this region of chromosome $17 \mathrm{q} 12-\mathrm{q} 21$ is ambiguous with respect to the presence and location of particular genes identified in the Human Genome Project. For instance, D17S746 has not been physically mapped relative to JUP in the Human Genome Project map. However, consistent with our data, Aberle et al (1995), have identified three recombinant cosmid clones of this region of human chromosome 17q21 that contained both D17S846 and JUP. It is possible, therefore, that the target gene for $\mathrm{LOH}$ on chromosome 17q21, in primary human breast tumours, could be located in the intervening nucleotide sequences between D17S846 and JUP (17 $489 \mathrm{bp}$, GenBank). At the present time, however, there is no evidence for a gene in this region of chromosome $17 \mathrm{q} 21$ in the Human Genome Project map.

Another possibility is that JUP is the target for LOH. JUP encodes $\gamma$-catenin or plakglobin and is highly homologous to $\beta$-catenin (Gumbiner, 1996). Both are components of cell-cell adherens junctions linking cadherin receptors to the actin cytoskeleton (Ben-Ze'ev and Geiger, 1998). In addition, plakoglobin is a component of desmosomes (Franke et al, 1989; Ben-Ze'ev and Geiger, 1998). Immunohistochemical analysis of primary human breast tumours for the expression of the catenin family demonstrated that if one of these proteins is downregulated, the function of the others in suppressing metastasis is altered (Bukholm et al, 1998; Gonzalez et al, 1999). In another study, it was shown that expression of plakoglobin was selectively downregulated in metastatic tumours (Bukholm et al, 2000). We have found no evidence that in tumours having LOH between D17S846 and D17S746 the remaining allele of JUP is mutated. Nor have we found evidence that the transcription promoter of JUP is methylated preventing transcription of the remaining allele in these tumours. Therefore, we speculate that haploinsufficiency of JUP caused by LOH is sufficient to contribute to breast tumour progression. A future study specifically aimed at correlating LOH of JUP and reduced plakoglobin levels in primary breast tumours seems warranted.

\section{ACKNOWLEDGEMENTS}

We are indebted to S Simek and W Franke for generously providing cloned cDNA probes, and $\mathrm{R}$ White for providing us with P1-phage clones $50 \mathrm{H} 1$ and 122F4.

\section{REFERENCES}

Aberle H, Bierkamp C, Torchard D, Serova O, Wagner T, Natt E, Wirsching J, Heidkamper C, Montagna M, Lynch HT, Lenoir GM, Schever G, Feunteun J, Kemler R (1995) The human plakoglobin gene localizes on chromosome $17 \mathrm{q} 21$ and is subjected to loss of heterozygosity in breast and ovarian cancers. Proc Natl Acad Sci USA 92(14): 6384-6388

Albertsen HM, Smith SA, Mazoyer S, Fujimoto E, Stevens J, Williams B, Rodriguez P, Cropp CS, Slijepcevic P, Carlson M, Robertson M, Sheng ZM, Hoops R, Sternberg N, Brothman A, Callahan R, Ponder B, White R (1994) A physical map and candidate genes in the BRCAl region on chromosome 17q12-21. Nat Genet 7(4): 472-479

Ben-Ze'ev A, Geiger B (1998) Differential molecular interactions of betacatenin and plakoglobin in adhesion, signaling and cancer. Curr Opin Cell Biol 10(5): 629-639

Bieche I, Khodja A, Driouch K, Lidereau R (1997) Genetic alteration mapping on chromosome 7 in primary breast cancer. Clin Cancer Res 3(6): $1009-1016$

Blanco MJ, Moreno-Bueno G, Sarrio D, Locascio A, Cano A, Palacios J, Nieto MA (2002) Correlation of Snail expression with histological grade and lymph node status in breast carcinomas. Oncogene 21(20): $3241-3246$

Bukholm IK, Nesland JM, Borresen-Dale AL (2000) Re-expression of Ecadherin, alpha-catenin and beta-catenin, but not of gamma-catenin, in metastatic tissue from breast cancer patients [see comments]. J Pathol 190(1): $15-19$

Bukholm IK, Nesland JM, Karesen R, Jacobsen U, Borresen-Dale AL (1998) E-cadherin and alpha-, beta-, and gamma-catenin protein expression in relation to metastasis in human breast carcinoma. $J$ Pathol 185(3): $262-266$

Coss MC, Winterstein D, Sowder II RC, Simek SL (1995) Molecular cloning, DNA sequence analysis, and biochemical characterization of a novel 65-kDa FK506-binding protein (FKBP65). J Biol Chem 270(49): $29336-29341$

Cropp CS, Champeme MH, Lidereau R, Callahan R (1993) Identification of three regions on chromosome $17 \mathrm{q}$ in primary human breast carcinomas which are frequently deleted. Cancer Res 53(23): 5617-5619

Cropp CS, Nevanlinna HA, Pyrhonen S, Stenman UH, Salmikangas P, Albertsen H, White R, Callahan R (1994) Evidence for involvement of BRCA1 in sporadic breast carcinomas. Cancer Res 54(10): 2548-2551

Dracopoli NC, Haines JL, Korf BR, Morton CC, Seidman CE, Seidman JG, Smith DR (eds) (1998) Methylation-Specific PCR. Current Protocols in Human Genetics. Hobokin, NJ: John Wiley \& Sons, Inc.

Franke WW, Goldschmidt MD, Zimbelmann R, Mueller HM, Schiller DL, Cowin P (1989) Molecular cloning and amino acid sequence of human plakoglobin, the common junctional plaque protein. Proc Natl Acad Sci USA 86(11): $4027-4031$

Gonzalez MA, Pinder SE, Wencyk PM, Bell JA, Elston CW, Nicholson RI, Robertson JF, Blamey RW, Ellis IO (1999) An immunohistochemical examination of the expression of E-cadherin, alpha- and beta/gammacatenins, and alpha2- and betal-integrins in invasive breast cancer. J Pathol 187(5): $523-529$

Gumbiner BM (1996) Cell adhesion: the molecular basis of tissue architecture and morphogenesis. Cell 84(3): 345-357

Herman JG, Graff JR, Myohanen S, Nelkin BD, Baylin SB (1996) Methylation-specific PCR: a novel PCR assay for methylation status of CpG islands. Proc Natl Acad Sci USA 93(18): $9821-9826$

Hongyo T, Buzard GS, Calvert RJ, Weghorst CM (1993) 'Cold SSCP': a simple, rapid and non-radioactive method for optimized single-strand conformation polymorphism analyses. Nucleic Acids Res 21(16): $3637-3642$

Knudson Jr AG (1971) Mutation and cancer: statistical study of retinoblastoma. Proc Natl Acad Sci USA 68(4): 820-823

Miyazaki S, Rasmussen S, Imatani A, Diella F, Sullivan DT, Callahan R (1999) Characterization of the Drosophila ortholog of mouse eIF-3p48/ INT-6. Gene 233(1-2): 241-247

Needleman SB, Wunsch CD (1970) A general method applicable to the search for similarities in the amino acid sequence of two proteins. J Mol Biol 48(3): 443-453

Osborne RJ, Hamshere MG (2000) A genome-wide map showing common regions of loss of heterozygosity/allelic imbalance in breast cancer. Cancer Res 60(14): 3706-3712

Osborne RJ, Merlo GR, Mitsudomi T, Venesio T, Liscia DS, Cappa AP, Chiba I, Takahashi T, Nau MM, Callahan R, Minna JD (1991) Mutations in the p53 gene in primary human breast cancers. Cancer Res 51(22): 6194-6198

Potter E, Braun S, Lehmann U, Brabant G (2001) Molecular cloning of a functional promoter of the human plakoglobin gene. Eur J Endocrinol 145(5): $625-633$

Siekierka JJ, Hung SH, Poe M, Lin CS, Sigal NH (1989) A cytosolic binding protein for the immunosuppressant FK506 has peptidyl-prolyl isomerase activity but is distinct from cyclophilin. Nature 341(6244): $755-757$ 
Smith T, Waterman M (1981) Comparison of bio-sequences. Adv Appl Math 2: $482-489$

Smithies O, Engels WR, Devereux JR, Slightom JL, Shen S (1981) Base substitutions, length differences and DNA strand asymmetries in the human G gamma and A gamma fetal globin gene region. Cell 26(3 Part 1): $345-353$

Staden R (1980) A new computer method for the storage and manipulation of DNA gel reading data. Nucleic Acids Res 8(16): 3673-3694

Standaert RF, Galat A, Verdine GL, Schreiber SL (1990) Molecular cloning and overexpression of the human FK506-binding protein FKBP. Nature 346(6285): $671-674$
Whittock NV, Eady RA, McGrath JA (2000) Genomic organization and amplification of the human plakoglobin gene (JUP). Exp Dermatol 9(5): $323-326$

Winn RA, Bremnes RM, Bemis L, Franklin WA, Miller YE, Cool C, Heasley LE (2002) Gamma-catenin expression is reduced or absent in a subset of human lung cancers and re-expression inhibits transformed cell growth. Oncogene 21(49): $7497-7506$

Yang Q, Nakamura M, Nakamura Y, Yoshimura G, Suzuma T, Umemura T, Shimizu Y, Mori I, Sakurai T, Kakudo K (2002) Two-hit inactivation of FHIT by loss of heterozygosity and hypermethylation in breast cancer. Clin Cancer Res 8(9): 2890-2893 